\title{
Exploitation of Aquatic Resources in Ahanve, Badagry, south-western Nigeria
}

\section{Orijemie, Emuobosa Akpo}

Cite this as: Orijemie, E.A. (2014). Exploitation of Aquatic Resources in Ahanve, Badagry, southwestern Nigeria. 'Human Exploitation of Aquatic Landscapes' special issue (ed. Ricardo Fernandes and John Meadows), Internet Archaeology 37. http://dx.doi.org/10.11141/ia.37.8

Department of Archaeology and Anthropology, University of Ibadan, Nigeria.

Email: orijemie5@yahoo.com

Keywords: Archaeology, Palaeoecology, Southern Nigeria, Aquatic resources, human-environment relationships, Cultural change

This issue has been funded by the Graduate School "Human Development in Landscapes", University of Kiel with additional funding from the Institute for Ecosystem Research, University of Kiel and the Centre for Baltic and Scandinavian Archaeology, Schloss Gottorf.

(C) Author(s). Except where otherwise noted, content from this work may be used under the terms of the Creative Commons Attribution 3.0 Unported licence, which permits unrestricted use, distribution, and reproduction in any medium, provided that attribution to the author(s), the title of the work, the Internet Archaeology journal and the relevant URL/DOI is given. 


\section{Summary}

The Badagry Cultural Area (BCA) is one of the significant socio-cultural places in coastal south-western Nigeria. Palynological and archaeological studies at Ahanve, a settlement in the BCA were undertaken recently to improve the understanding of past human exploitation of aquatic resources. Collected data revealed contrasts in the availability and utilisation of aquatic resources between a first occupation phase (9th-17th centuries $A D$ ) and a second occupation phase (17th century $A D$ to present). The environment during the first phase was characterised by secondary forest and freshwater swamp. During this period, the inhabitants consumed cat-fish (Clariidae) and bivalves (Anodonta sp.), and engaged in salt production. The salt was produced from brine obtained from the Atlantic Ocean. Aquatic food resources were supplemented with terrestrial animal and plant foods. During the second occupation phase, aquatic resources (cat-fish and bivalves) declined and subsequently disappeared; salt production was discontinued while terrestrial foods, particularly plant-based types, increased significantly. These events coincided with the arrival of European travellers. Oral sources suggest that the decline in the exploitation of aquatic resources was in part due to the fear of being taken captive while on fishing expeditions, restrictions by Europeans who controlled the water-ways, and the massive importation of salt which replaced local production. 


\section{List of Figures}

Figure 1: Map of the Badagry Cultural Area (BCA) showing sites mentioned in the text (Image credit: E.A. Orijemie)

Figure 2: TPI at surface level (Image credit: E.A. Orijemie)

Figure 3: TPI at level 90-100cm (Image credit: E.A. Orijemie)

Figure 4: Stratigraphic sections of the northern and eastern walls of TPI (Image credit: E.A. Orijemie)

Figure 5: Aquatic resources recovered from Ahanve, a. cranial bones of Clariidae, b. shell of a bivalve (Anodonta sp.) and c. salt residue (Image credit: E.A. Orijemie)

Figure 6: Broken stems and bowls of smoking pipes recovered from Ahanve (Image credit: E.A. Orijemie)

\section{List of Tables}

Table 1: Materials recovered from Ahanve TPI

Table 2: Soil colours of stratigraphic layers delineated in TPI

Table 3: Radiocarbon dates from the study area

\section{Introduction}

The place of the Badagry Cultural Area (BCA) in the recent history of Western Nigeria is undoubtedly significant; it was one of the embarking points for slaves (mostly Nigerians) towards the Americas until the 19th century. Its location near the Atlantic Ocean contributed to the siting of two sea ports there, firstly at Apa (Owode-Apa in Figure 1) between $1700 A D$ and $1800 A D$, and then later in Badagry main town between $1800 A D$ and 1900 AD. These ports were to serve as administrative posts for European colonists, both to control the transatlantic slave trade and to quell any rebellion by the indigenes. Apa was chosen as a port because of its strategic location and cultural status; it is located at the bend 
where the Yewa River and the Badagry creek meet (Figure 1) and is traditionally regarded as the oldest settlement in the BCA.

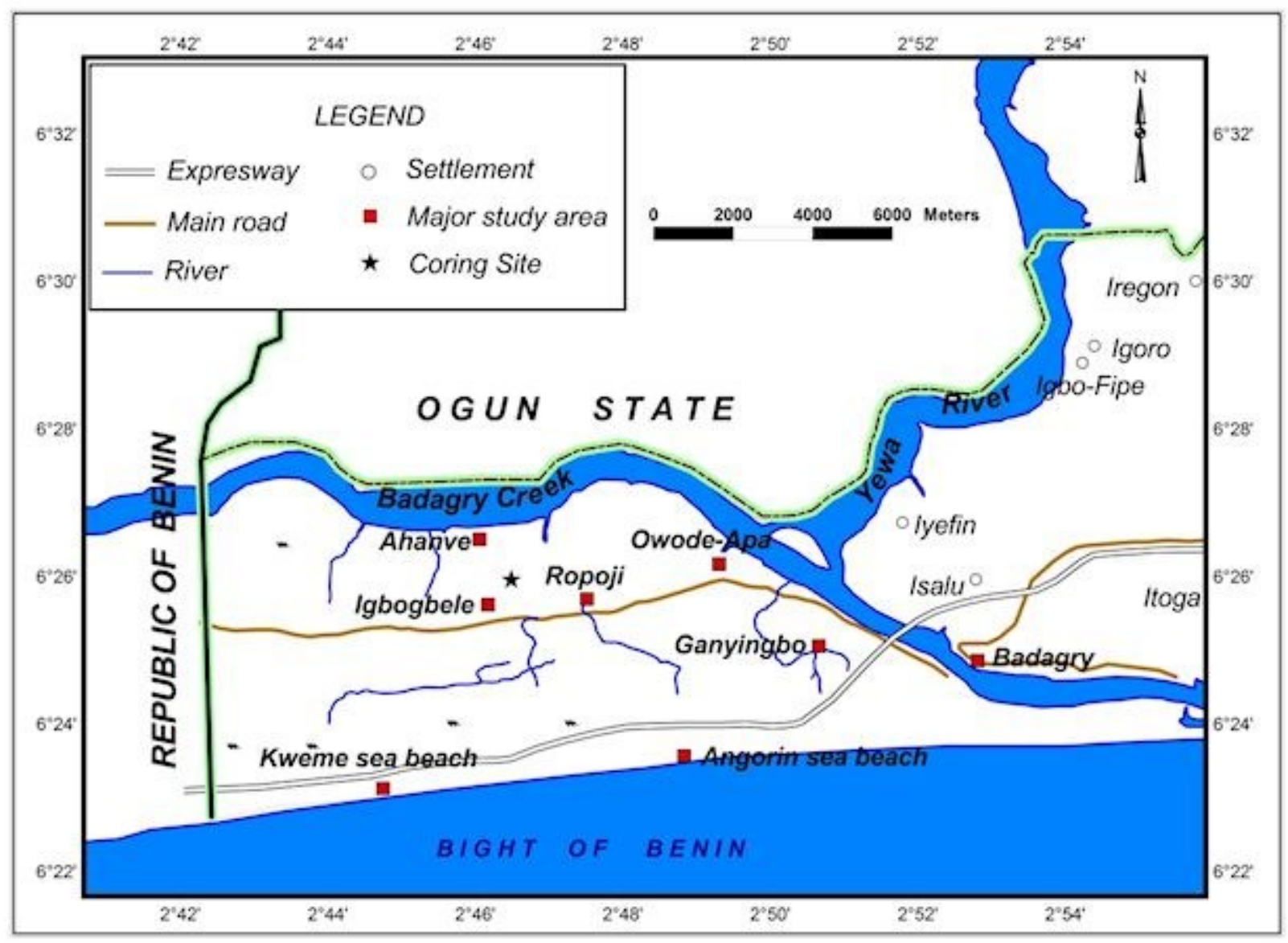

Figure 1: Map of the Badagry Cultural Area (BCA) showing sites mentioned in the text (Image credit: E.A. Orijemie)

Radiocarbon dating of a charcoal sample obtained from $1.75 \mathrm{~cm}$ of unit AP1 in Apa indicates that human occupation dates back to $2670 \pm 90$ BP [Beta-89266] (Alabi 1998). Subsistence economy during the earliest occupation up until the recent past included the use of oil palm trees and palm kernels and perhaps food production (Alabi 1998; 2002). The recovery of ground stone axes, charcoal and charred palm kernels from Apa (Alabi 1998) indicated that the people used fire to clear part of the forest. Although no remains of domesticated plants or animals were recovered in West Africa, the occurrence of charred palm kernel has been linked with the sudden increase in oil palm pollen (Sowunmi 1999). Oil palm trees are deliberately protected during slash-and-burn carried out in preparation for farming. Other radiocarbon and thermoluminescence dates from Apa (360 \pm 50 BP/cal AD 1440-1655 [Beta91940]) and Ganyingbo beach (cal AD $1660 \pm 58 / 290 \pm 20 \%$ BP [Alpha-3192) (AllsworthJones and Wesler 1998) respectively suggest human activities in the BCA from the 15 th to 
17th centuries. Outside Apa and Ganyingbo, little information was hitherto available from other towns in the BCA.

Ahanve is an important settlement in the BCA. Its original name was Ahanfe, i.e. Ahan ife, which in Yoruba means 'to show/express love' but is now written Ahanve, which is the official name of the village today. Ahanve is regarded as an ancient settlement established by populations originating from Apa. It is located along the swamps of the Badagry creek and Yewa River, which adjoin the Atlantic Ocean. It is about $13 \mathrm{~km}$ west of Badagry and about $4.5 \mathrm{~km}$ west of Apa (Figure 1). It is bounded on the west by the Nigerian-Bénin border as well as adjoining villages, on the east by the Badagry creek and Yewa River, on the north by the southern parts of Ogun State and on the south by the Kweme, Angorin and Ganyingbo beaches, as well as the Atlantic Ocean. The present-day vegetation is a freshwater swamp dominated by Typha australis (Sowunmi 2004; Orijemie and Sowunmi 2014); T. domingensis is present but it is not as abundant as T. australis. Also present are communities of secondary and freshwater swamp forests, and some cultivars such as Manihot esculenta (cassava), Capsicum sp. (pepper), Colocasia sp. (cocoyam) and Citrus sp. (orange). Ahanve has an annual temperature range of between $24^{\circ} \mathrm{C}$ and $29^{\circ} \mathrm{C}$. Rainfall, which is controlled mainly by the movement of the Inter Tropical Divergence (ITD) ranges from $1500 \mathrm{~mm} / \mathrm{yr}$ to $1800 \mathrm{~mm} / \mathrm{yr}$ (Adejuwon 1970).

Palynological analyses of cores obtained from the Typha swamp near the present-day settlement at Ahanve indicated that during the early to mid-Holocene (9000-5500 uncal BP), lowland rainforest and mangrove swamp forest dominated the environment. The mangrove swamp forest disappeared while the primary rain forest declined c. $3109 \pm 26$ uncal BP (1440-1310 cal BC) [KIA-17574] (Sowunmi 2004). The main factors responsible for this were suggested to be primarily climatic, hydrologic and geomorphologic; but humans probably also contributed to a decline in rain forest area (Sowunmi 2004; Orijemie 2013). This last suggestion is in part based on marked increases in microscopic charcoal and the occurrence of pollen of plants associated with human disturbance at the time the mangroves disappeared and the primary forest declined, and partly on a radiocarbon date obtained from Apa $(2,670 \pm 90 \mathrm{BP})$. Therefore, since humans were already present in the BCA about 2700 yrs uncal BP, it is desirable to ascertain how they interacted with the environment. To this end, archaeological, ethnographic and palynological investigations were undertaken. As this is a swampy environment, aquatic resources were given particular attention in terms of their availability and use, as well as their impact on the subsistence economy of Ahanve. 


\section{Archaeological Excavation}

After consultations with the Chiefs of Ahanve, two sites (TPI and TPII) were chosen for excavation on the basis of the ethnographic evidence they provided. The report here is only on the excavated unit TPI ( $2 \times 1 \mathrm{~m} ; 2.10 \mathrm{~m}$ deep; $\left.6.43138^{\circ} \mathrm{N}, 2.77532^{\circ} \mathrm{E}\right)$, since it is the only one dated so far. TPI is a refuse mound located in a bush hitherto regarded as 'evil forest'. Excavation proceeded at spit levels of $10 \mathrm{~cm}$ and was terminated at a sterile layer reached at 2.05-2.10m. Excavated materials were sieved through a $10 \mathrm{~mm}$ mesh and sorted into welllabelled bags. Vessel forms were reconstructed based on rim morphology and a diameter chart. The animal remains were taken to the Museum of the Department of Zoology, University of Ibadan, Nigeria, for identification and soil colour was determined with reference to a Munsell Colour Chart. Pieces of charcoal and charred palm kernels were sent for radiocarbon dating at the Beta Analytic Laboratory, Florida, USA. Samples were subjected to acid/alkali/acid pretreatment in which they were gently crushed/dispersed in deionized water and treated with hot $\mathrm{HCL}$ and $\mathrm{NaOH}$ before combustion.

\subsection{The sediment core and palynological analysis}

A $2 \mathrm{~m}$ sediment core was obtained from the freshwater swamp $\left(6.43195^{\circ} \mathrm{N}, 2.77475^{\circ} \mathrm{E}\right.$, $0.5 \mathrm{~m}$ asl) in Ahanve village (Figure 1 ) using a Hiller corer. In the field, sub-samples were collected at intervals of $10 \mathrm{~cm}$ and wrapped in well-labelled aluminium foil. One gram of the sub-samples was processed using the standard method of Faegri and Iversen (1989). Identification of palynomorphs (pollen and spores) was done to family, generic or species levels based on photomicrograph albums and the collection of 3600 reference slides in the Palynology Laboratory, Department of Archaeology and Anthropology, University of Ibadan, as well as the following publications: Erdtman (1966); Sowunmi $(\underline{1973}$; 1995) and SalardCheboldaeff (1980; 1981).

\section{Results}

\subsection{Ethnography}

The BCA is inhabited mainly by the Yoruba people. Historically, they comprise two subgroups, namely Ogu (corrupted to Egun) and Awori. The former claims to have migrated from the southern parts of Bénin Republic (formerly Dahomey), Togo and Ghana while the latter claims an Ile-Ife origin. Linguistically, Ogu can be referred to as a dialect of Yoruba and is similar to the Bénin Republic languages of Fon and Aja (Dr Demola Lewis, pers. comm. 2011). A peculiarity of the Ahanve people is their ability to speak both Yoruba and Ogu 
languages, although they claim to have migrated from Ile-Ife, having first stopped at Apa before settling in their present location (Chief G.J. Toyon, pers. comm. 2008). Being close to the Atlantic Ocean, Ahanve had early European contacts, and came directly under colonial rule in the 19th century.

\subsection{Palynology}

Pollen results indicate that sometime before c. 3100 uncal BP, Ahanve was dominated by diverse and extensive lowland rain forest (LRF) and mangrove swamp forest (MSF) (Sowunmi 2004; Orijemie 2013). From c. 4500-3500 BP the LRF declined sharply, and MSF disappeared, while freshwater swamp forest increased due mainly to the onset of drier climate and lowered sea level. The LRF and MSF were replaced by secondary forest and coastal savannas after c. 3100 BP. In addition, herbaceous and weedy plants associated with human habitation, together with microscopic charcoal particles, had a marked increase at the top of the core.

\subsection{Archaeology}

Materials recovered from the excavation were pottery, charcoal, smoking pipes (local and foreign), animal bones, rusty nails (iron objects), iron slag, snail shells, broken glass/bottles, palm kernels and a hearth. Pottery was the most abundant find recovered from the excavations (64.4\%, Table 1). Decoration motifs included carved wood roulette, wavy lines, incisions, comb teeth impression, incised and grooved, herringbone impression, single-string cord roulette, finger impressions, and deep incisions. Most significant was the recovery of the classical Ile-Ife motif, i.e. incised and grooved (Garlake 1974), at the lowest levels of TPI. The reconstructed vessel forms based on a random selection of 55 rims included large pots of $61-80 \mathrm{~cm}$ in diameter, medium-sized pots of $35-55 \mathrm{~cm}$ in diameter, small pots of $30 \mathrm{~cm}$ in diameter and bowls $(10-20 \mathrm{~cm}$ in diameter). Of the 55 rims selected, large pots constituted $14.6 \%$, medium-sized pots, $23.6 \%$; small pots, $29.1 \%$ and bowls, $32.7 \%$. Aquatic resources included cat-fish bones, bivalves and salt residues (Table 1). The salt residues were identified by Chief Suru Toyon, a 78-year old Ahanve elder in 2008; he had engaged in salt production when he was a boy. On the basis of the occurrence of foreign smoking pipes at $120-130 \mathrm{~cm}$, two phases of human occupation were delineated: Phase I $(130-210 \mathrm{~cm})$ and Phase II $(0-130 \mathrm{~cm})$ (Table 1). 


\begin{tabular}{|c|c|c|c|c|c|c|c|c|c|c|c|c|c|c|c|}
\hline & Depth/materials & Pottery & $\begin{array}{l}\text { Animal } \\
\text { bones }\end{array}$ & $\begin{array}{l}\text { Fish } \\
\text { bones }\end{array}$ & $\begin{array}{l}\text { Snail } \\
\text { shells }\end{array}$ & Bivalves & $\begin{array}{l}\text { Smoking } \\
\text { pipes }\end{array}$ & $\begin{array}{l}\text { Salt } \\
\text { residues }\end{array}$ & $\begin{array}{l}\text { Iron } \\
\text { slag }\end{array}$ & $\begin{array}{l}\text { Iron } \\
\text { object }\end{array}$ & Charcoal & Stone & $\begin{array}{l}\text { Palm } \\
\text { kernel }\end{array}$ & Glass & $\begin{array}{l}\text { Gross } \\
\text { total }\end{array}$ \\
\hline \multirow{13}{*}{$\begin{array}{l}\text { Phase } \\
\text { II }\end{array}$} & $0-10 \mathrm{~cm}$ & 3 & & & 10 & & & & 1 & 1 & 41 & & 2 & & 58 \\
\hline & $10-20 \mathrm{~cm}$ & 2 & & & 2 & & & & & & 30 & & 3 & & 37 \\
\hline & $20-30 \mathrm{~cm}$ & 116 & & & 1 & & & 1 & & & 26 & & 19 & & 163 \\
\hline & $30-40 \mathrm{~cm}$ & 3 & & & & & & & & & 39 & & 11 & & 53 \\
\hline & $40-50 \mathrm{~cm}$ & 40 & & & & & & & & & 63 & & 4 & 2 & 109 \\
\hline & $50-60 \mathrm{~cm}$ & 60 & 13 & & 7 & & & 1 & 1 & & 18 & & & & 100 \\
\hline & $60-70 \mathrm{~cm}$ & 96 & 40 & & & & 2 & & 2 & & 13 & & & & 153 \\
\hline & $70-80 \mathrm{~cm}$ & 33 & & & & & 1 & 3 & & 1 & 8 & 1 & & & 47 \\
\hline & $80-90 \mathrm{~cm}$ & 54 & 1 & & 1 & 1 & & & 2 & 1 & 40 & & 4 & & 104 \\
\hline & $90-100 \mathrm{~cm}$ & 227 & & & & & 1 & & 2 & & 12 & & 3 & & 245 \\
\hline & $100-110 \mathrm{~cm}$ & 287 & & & 9 & & 4 & & & & 6 & & 6 & & 312 \\
\hline & $110-120 \mathrm{~cm}$ & 221 & 109 & 8 & 1 & 1 & 1 & & & & 7 & 1 & 5 & & 354 \\
\hline & $120-130 \mathrm{~cm}$ & 128 & 54 & & & & 1 & 2 & 1 & & 23 & & 5 & & 214 \\
\hline
\end{tabular}




\begin{tabular}{|c|c|c|c|c|c|c|c|c|c|c|c|c|c|c|c|}
\hline \multirow{8}{*}{$\begin{array}{l}\text { Phase } \\
\text { I }\end{array}$} & $130-140 \mathrm{~cm}$ & 169 & 93 & 6 & 6 & & & 1 & 3 & & 56 & & 5 & & 339 \\
\hline & $140-150 \mathrm{~cm}$ & 107 & 79 & 1 & & & & 4 & 1 & & 50 & & 5 & & 247 \\
\hline & $150-160 \mathrm{~cm}$ & 305 & 16 & 1 & & & & 2 & 2 & & 18 & & 2 & & 346 \\
\hline & $160-170 \mathrm{~cm}$ & 160 & 15 & 3 & & & & 2 & 3 & & 7 & & 17 & & 207 \\
\hline & $170-180 \mathrm{~cm}$ & 176 & 55 & 5 & & 1 & & 1 & 2 & & 35 & & 11 & & 286 \\
\hline & $180-190 \mathrm{~cm}$ & 162 & 22 & 13 & & & & 7 & 1 & & 46 & 1 & 29 & & 281 \\
\hline & $190-200 \mathrm{~cm}$ & 82 & & 5 & 22 & & & 3 & & & 5 & 3 & 1 & & 121 \\
\hline & $200-210 \mathrm{~cm}$ & 10 & & & 3 & & & & & & & & & & 13 \\
\hline \multicolumn{2}{|c|}{ Total number of individual finds } & 2441 & 497 & 42 & 62 & 3 & 10 & 27 & 21 & 3 & 543 & 6 & 132 & 2 & 3789 \\
\hline \multicolumn{2}{|c|}{ \% Occurrence of finds } & 64.4 & 13.1 & 1.1 & 1.6 & 0.07 & 0.3 & 0.7 & 0.5 & 0.07 & 14.3 & 0.2 & 3.5 & 0.05 & \\
\hline
\end{tabular}



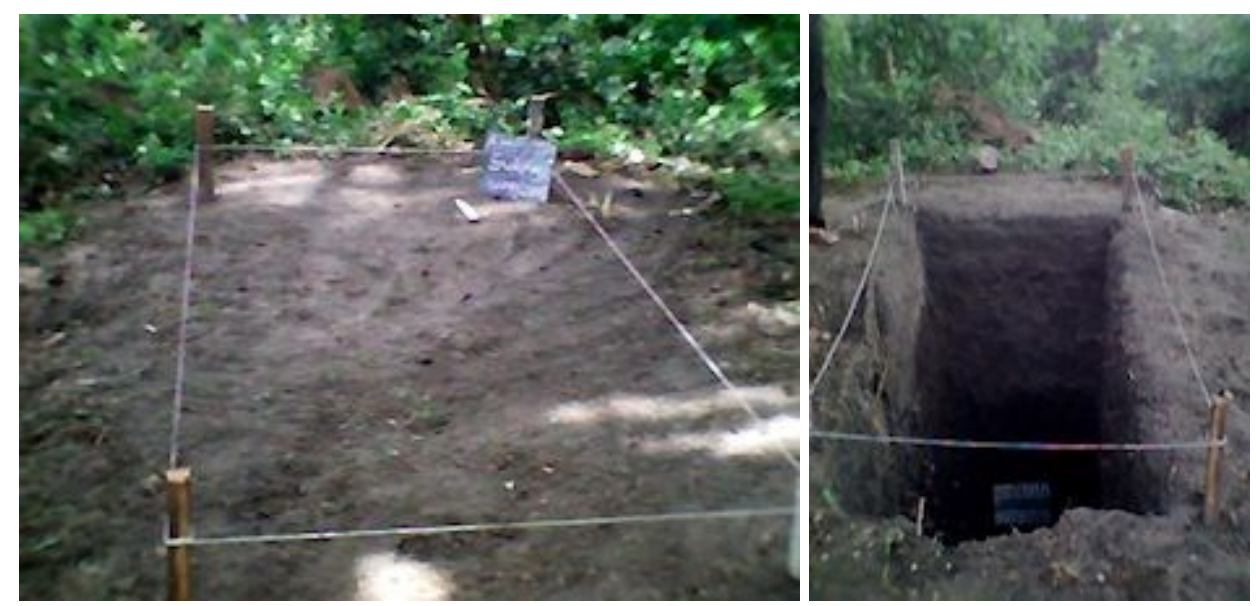

Figure 2: TPI at surface level (Image credit: E.A. Orijemie)

Figure 3: TPI at level $90-100 \mathrm{~cm}$ (Image credit: E.A. Orijemie)

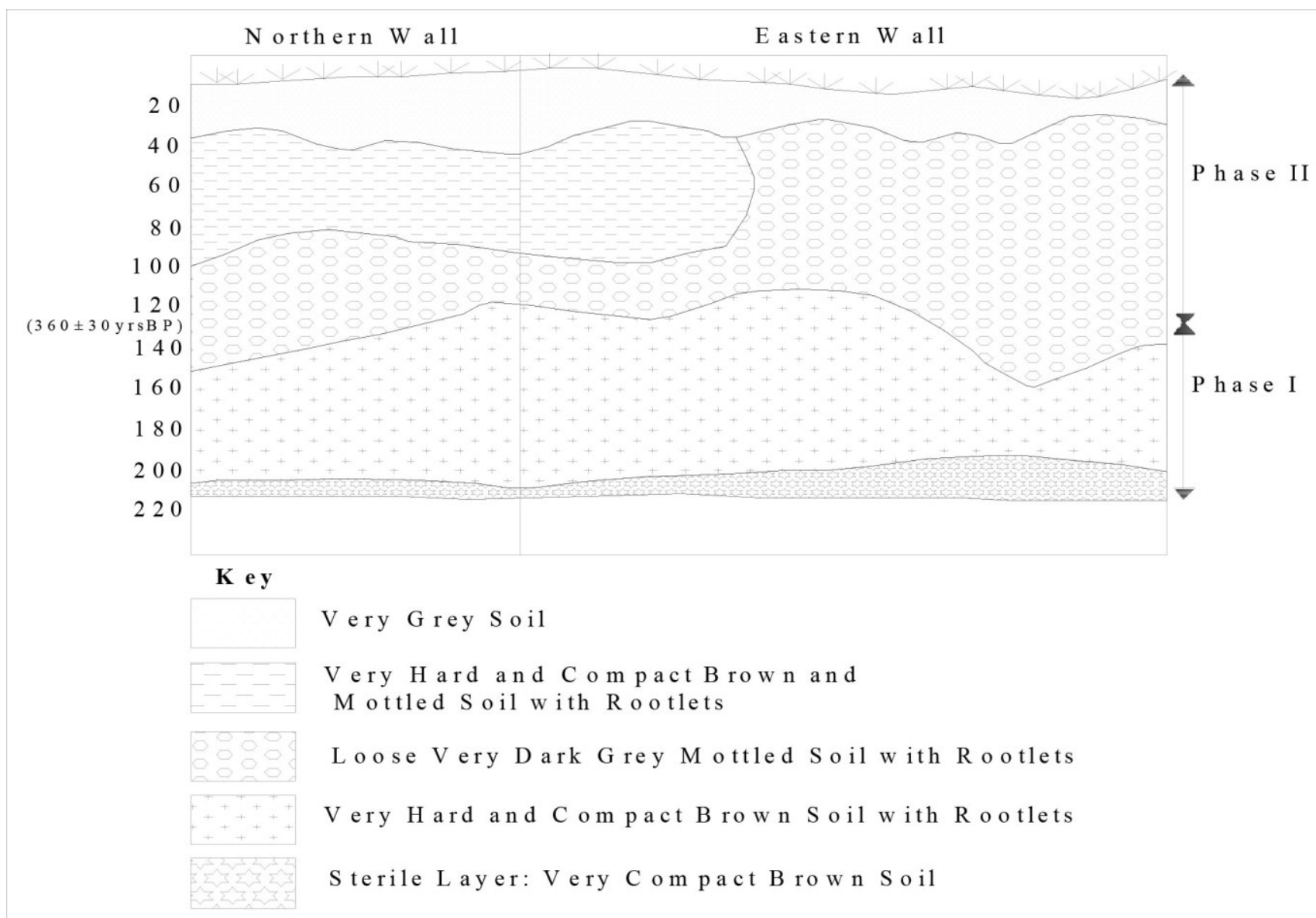

Figure 4: Stratigraphic sections of the northern and eastern walls of TPI (Image credit: E.A. Orijemie) 


\subsection{Stratigraphic layers}

\begin{tabular}{|l|l|l|}
\hline \multicolumn{3}{|l|}{ Table 2: Soil colours of stratigraphic layers delineated in TPI } \\
\hline Layer & TPI & Soil \\
\hline 1 & Dark grey & Sand \\
\hline 2 & Dark yellowish-brown & Sand \\
\hline 3 & Black & Sand \\
\hline 4 & Dark yellowish-brown & Sand \\
\hline 5 & Dark brown & Sand \\
\hline
\end{tabular}

Five distinct layers were identified based on marked changes in soil colour (Figure 4). The layers are described below, and shown in Table 2. The first layer in the excavated unit, layer 1 , was the sterile layer $(205-210 \mathrm{~cm})$; the soil in this layer was very compact and dark grey in colour. The soil type was sand. Layer $2(150-205 \mathrm{~cm})$ was a very hard and compact soil, with rootlets; it was dark yellowish-brown in colour and the soil type was sand. It contained large snail shells (Archachatina marginata) but very little pottery. The soil in layer $3(100-150 \mathrm{~cm})$ was loose and mottled with rootlets and black in colour. The soil type was sand; the first appearance of smoking pipes was recorded here. Layer $4(30-100 \mathrm{~cm})$ was very hard and compact; it was mottled with rootlets and dark yellowish-brown in colour. The soil type was sand. No fish bones were seen in this layer while bivalves only occurred once in the unit. Layer $5(0-30 \mathrm{~cm})$ was loose and dark grey in colour; the soil type was sand. It contained recent European products such as nails and pieces of gin bottles, as well as abundant charcoal and palm kernels. 

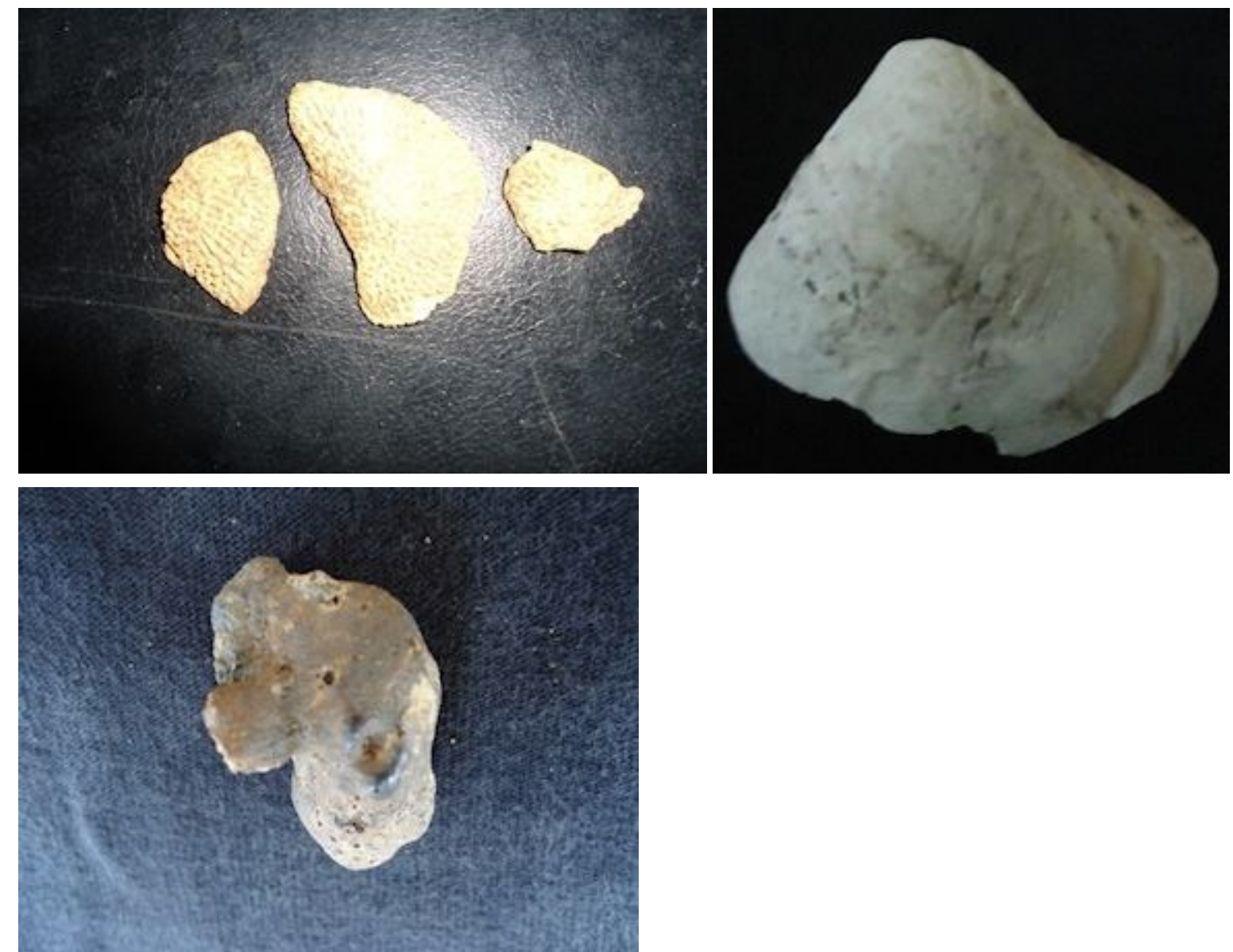

Figure 5: Aquatic resources recovered from Ahanve, a. cranial bones of Clariidae, b. shell of a bivalve (Anodonta sp.) and c. salt residue (Image credit: E.A. Orijemie) 

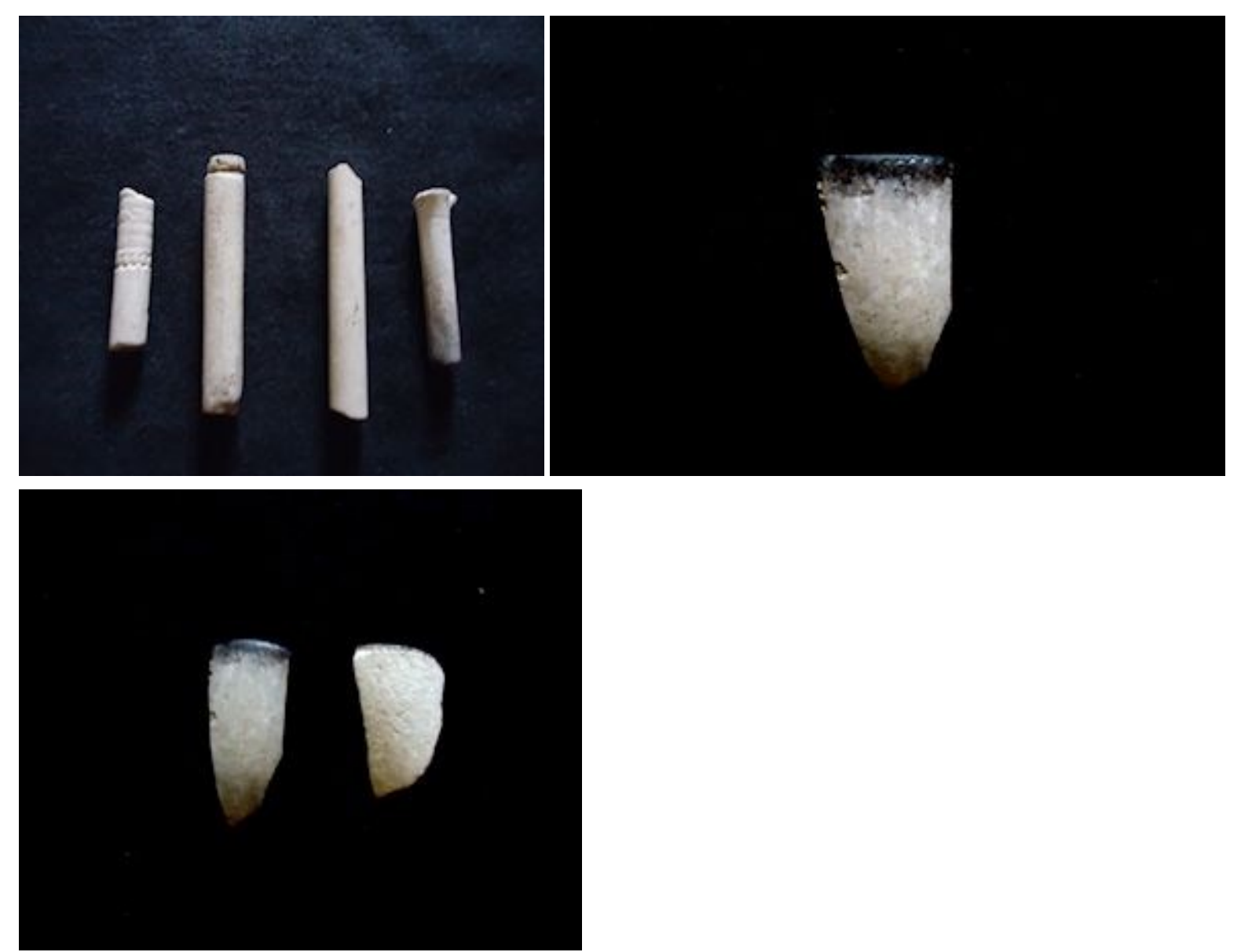

Figure 6: Broken stems and bowls of smoking pipes recovered from Ahanve (Image credit: E.A. Orijemie) 


\begin{tabular}{|c|c|c|c|c|c|c|}
\hline Site & $\begin{array}{l}\text { Lab. } \\
\text { number }\end{array}$ & $\begin{array}{l}\text { Depth } \\
(\mathrm{cm})\end{array}$ & $\begin{array}{l}\text { Sample } \\
\text { material } \\
\text { dated }\end{array}$ & $\begin{array}{l}\text { Conventional } \\
\text { C14 age }\end{array}$ & Calendar date & $\delta^{13} \mathrm{C}$ \\
\hline $\begin{array}{l}\text { Ahanve } \\
\text { TPI }\end{array}$ & $\begin{array}{l}\text { Beta- } \\
296134\end{array}$ & $\begin{array}{l}180- \\
190\end{array}$ & $\begin{array}{l}\text { Charcoal and } \\
\text { charred palm } \\
\text { kernels }\end{array}$ & $260 \pm 30 \mathrm{BP}$ & $\begin{array}{l}\text { Cal AD 1640-1670 } \\
\text { (Cal BP 310-280) (1 } \\
\text { sigma) or Cal AD } \\
1520-1800 \text { ( } 2 \\
\text { sigma) }\end{array}$ & $-26.3 \%$ \\
\hline $\begin{array}{l}\text { Ahanve } \\
\text { TPI }\end{array}$ & $\begin{array}{l}\text { Beta- } \\
296133\end{array}$ & $\begin{array}{l}130- \\
140\end{array}$ & $\begin{array}{l}\text { Charcoal and } \\
\text { charred palm } \\
\text { kernels }\end{array}$ & $360 \pm 40 \mathrm{BP}$ & $\begin{array}{l}\text { Cal AD 1450-1520 } \\
\text { (Cal BP 500-430) (1 } \\
\text { sigma) or Cal AD } \\
1440-1640 \text { (Cal BP } \\
510-310) \text { ( } 2 \text { sigma) }\end{array}$ & $-24.6 \%$ \\
\hline $\begin{array}{l}\text { Ahanve } \\
\text { core }\end{array}$ & $\begin{array}{l}\text { KIA- } \\
17574\end{array}$ & $32-34$ & $\begin{array}{l}\text { Silty peat + } \\
\text { charred plant } \\
\text { fragments }\end{array}$ & $3109 \pm 26 \mathrm{BP}$ & $\begin{array}{l}1440-1310 \text { cal BC } \\
\text { (Cal BP 3390-3260) }\end{array}$ & $-\overline{24.57 \% 。}$ \\
\hline
\end{tabular}

Note: The Pretoria Calibration Procedure was used for the calendar calibrations. In describing the calibration curves one sigma statistics of $68 \%$ probability and two sigma statistics of $95 \%$ probability were followed.

\section{Discussion - The Exploitation of Aquatic Resources}

\subsection{Ninth-seventeenth centuries}

The radiocarbon date $(260 \pm 30 \mathrm{yrs}$ BP) obtained from level $180-190 \mathrm{~cm}$ of the excavated unit appears younger than that from a stratigraphically higher level $(130-140 \mathrm{~cm})$ (Table 1$)$. This result was very unexpected and difficult to explain considering that there were no disturbances in the stratigraphy of the excavated unit. Hence, the earliest date for the arrival of the Ahanve people in their present location is inferred from about the time they left their ancestral home, Ile-Ife. That there was some relationship between Ahanve and IleIfe is supported by the recovery of pottery with classical Ile-Ife decoration motifs (incised and grooved) from the lowest levels of the Ahanve excavation (Orijemie 2013). Thus it is 
inferred that Ahanve people probably migrated from lle-Ife after the 9th century; this is the oldest date yet recovered from Ile-Ife (Garlake 1974; Babalola, pers. comm. 2012). It is also possible this migration occurred any time between the 9th-17th centuries AD. The oldest dates yet recovered from Ahanve are cal AD 1440-1640. When the people arrived in Ahanve a variety of food resources was available including a range of 'bush' (i.e. forest) animals like baboons for example, African giant snails, cat-fish, bivalves (Figure 5), salt and Typha australis. I will focus on the aquatic resources.

In Phase I, Ahanve people engaged in fishing. The cranial bones recovered from the excavation were identified as those of Clariidae (cat-fish) (Mrs Folorunso, pers. comm. 2011). Among the Clariidae, Clarias gariepinus is the most common in Nigeria; though tolerant of many habitats it is natural to freshwater environments (Vitule et al. 2006; Fishbase). Hence its recovery in the Ahanve excavation does suggest the presence of freshwater nearby. This inference is further strengthened by pollen evidence, which reveals that Ahanve has been dominated by freshwater swamp for the last $c$. 3000 years (Sowunmi 2004). Furthermore, from that time until the present, there has been no significant change in the hydrology of the area, hence Clariidae is still caught in the Ahanve swamp, and eaten today in Ahanve.

Bivalve shells (Anodonta sp.) were recovered whole (Figure 5b), an indication that this shellfish might have been eaten. Bivalve shells are used for paving floors in rural coastal communities in Southern Nigeria, though this was not observed in Ahanve. To use the shells for this purpose, the flesh must first be removed and it is unlikely it would be discarded. However, the very low number recovered (Table 1) suggests Anodonta were probably an insignificant part of the people's diet. Anodonta sp. is natural to freshwater environments (Ugwoke et al. 2013). Its recovery from the excavation lends credence to the inference made earlier about the presence of freshwater. Another item worthy of note and which served several purposes (cooking, preservation of foods and dyeing) is salt. According to Allsworth-Jones and Wesler (1998), the process of salt production in Angorin and Ganyingbo sea beaches in the BCA involves boiling brine from the Atlantic Ocean in large clay vessels and/or pots. After evaporation, a grey-white sludge or paste is formed. After cooling, this substance is scooped and rewashed to remove dirt; the residue is salt. This process, which was in use as early as the 15th century on the West African coast (Allsworth-Jones and Wesler 1998), is like that at Ahanve at present but with a few differences. In Ahanve, large pots were used for salt production and, upon evaporation, a whitish rock-like substance crystallises at the bottom of the pots. This substance is then washed, the dirt (soil and other debris) is discarded, and the salt that remains is ground into small particles and eventually sold in the market (Tunde Toyon, pers. comm. 2013). Large pots of $61-80 \mathrm{~cm}$ in diameter, possibly used for salt production, were recovered from the Ahanve excavation. In addition, 
salt residues were recovered from the excavated unit in Ahanve, particularly at the lowest levels (Table 1). Ahanve today is c. $6.3 \mathrm{~km}$ from the coast, unlike towns such as Angorin and Ganyingbo sea beaches which are less than $219 \mathrm{~m}$ from the coast and have salt production traditions. Did the Ahanve people engage in salt production, considering its much greater distance from the Atlantic Ocean?

TPI was on a refuse mound and the recovered salt residues reflected the small-scale production of salt for domestic rather than industrial purposes. The Angorin and Ganyingbo sea beaches (Allsworth-Jones and Wesler 1998) and Gberefu (Alabi 1998) were considered to be industrial salt production sites based on the presence of numerous mounds and associated pottery there. It is a well-known fact that salt production along the Gulf of Guinea in the 14th-18th centuries was very common. Avoseh (1938) reported that a saltmaking tradition was prominent in the BCA between the 16th and 18th centuries. Furthermore, salt production in the Lagoon of Bénin Republic was reported by Rivallain (1977, in Allsworth-Jones and Wesler 1998). Lagoons in Bénin Republic are directly linked to the Atlantic Ocean and thus are highly saline, whereas Badagry creek and the Yewa River are freshwater bodies that could not have been used for salt production. Ahanve oral traditions indicated that salt was produced locally; the archaeological evidence, i.e. the recovery of salt residues and the reconstructed large vessels, seem to support this. However, unlike Angorin and Ganyingbo sea beaches, the few salt residues recovered indicated that salt production in Ahanve was most probably done on a small scale, perhaps by a few individuals and/or families. The high cost of labour and fuel contributed to the subsequent abandonment of the trade. Salt was later acquired at the Badagry market, where other saltproducing peoples came to sell their products.

\subsection{Seventeenth-twentieth centuries}

Post $360 \pm 40$ BP (cal AD 1440-1640), fish remains disappeared and salt residues declined significantly (Table 1). These events coincided with the appearance of Dutch smoking pipes (Table 1), signalling the arrival of Europeans. It is known that England, France, Denmark and Sweden exported Dutch pipes to West Africa during the 17th and 19th centuries (Walker 1975). The pipes recovered from Ahanve have no marks or inscriptions but have a 'milled rim' feature on their surface and a 'delicate cog-wheel-like denticulation round the bowl rim' (Walker 1975, 185) (Figure 6). These are characteristic features of Dutch smoking pipes. In addition, the Dutch established a trading post in Apa prior to 1734 until 1736, when it was moved to Badagry by Hendrick Hertog for economic reasons (Alabi 1998). The proximity of Ahanve to Apa accounts for the occurrence of Dutch pipes in Ahanve.

Europeans have visited the West African coast since the 15th century (DeCorse 2001). Initially, the focus of their attention was on the western side of the region. Their presence in 
Nigeria became prominent in the 16-17th centuries. Ahanve traditions indicated that during the transatlantic slave trade there were restrictions, particularly on fishing expeditions and transportation on the water-ways (Chief Suru Toyon, pers. comm. 2008). Persons who violated these restrictions ran the risk of being captured and sold as slaves. Although these alone do not satisfactorily explain the non-recovery of fish remains from the excavated unit, what is clear is that consumption of fish declined drastically in Phase II. Palynological evidence from the topmost levels $(0-20 \mathrm{~cm})$ of the sediment core indicated that during this phase there was abundant pollen of weeds and plants associated with agriculture, and human disturbances of vegetation, as well as microscopic charcoal (Orijemie 2013). The pattern of increase in microscopic charcoal indicated that the fires were continuous and regular in occurrence, features consistent with anthropogenic fires. In addition, the marked increase in the pollen of weeds and plants associated with human habitation and cultivated areas indicate that there was increased reliance on plant-based resources. Another possibility is increased human population, but there is as yet no demographic evidence of Ahanve during this period. The recovery of bivalves below $80 \mathrm{~cm}$ depth in the excavated unit but not above indicated continuous usage up until that point. Ahanve, and indeed the BCA, was terrorised by mainly ljebu slave raiders, who ravaged the area during the trans-Atlantic slavery period. These raids led to Ahanve being internally displaced at some point. The scarcity of finds such as pottery and charcoal, and absence of palm kernels between $80 \mathrm{~cm}$ and $50 \mathrm{~cm}$ depth are indications Ahanve was either sparsely populated or abandoned at those times. In addition, pressures from slaving activities and the trauma of being subsumed under foreign authorities led to disruption of the socio-political lives of the people. The disruption was severe to the extent that Dahomean soldiers were able to raid the BCA between the 18th and 19th centuries without any resistance as they destroyed towns and took people to be sold into slavery. The European colonists did little to prevent these raids, which supported their own need for a source of slaves. Old Oyo, under whose protection the BCA had been, could not help because it had been consumed by a combination of Hausa-Fulani forces and traitor chiefs (Morgan 1971).

The decrease in the occurrence of salt residues is an indication that salt production was probably discontinued. Considering the importance of salt, indigenous production would have been discouraged particularly where a cheaper and less laborious alternative existed. Oral traditions stated that an embargo was placed on indigenous salt production to allow for massive importation of European salt. Consequently, imported salt took precedence over locally made products as it does today. Due to the abandonment of salt production, this aspect of the people's material culture is almost lost as the trade is rarely practised today. In fact, only a very few elderly persons can replicate the indigenous salt production technique. 
The saltwater fern, Acrostichum aureum, is regarded as a highly medicinal plant in Ahanve. The roots are considered poisonous, hence are not consumed. However, concoctions from the roots are used as ointment for newborn babies. Acrostichum aureum is also used by the people to treat skin infections and severe stomach ache. The analgesic and antiinflammatory properties of Acrostichum aureum have been confirmed by Khan et al. (2013) and Hossain et al. (2011) respectively. It is remarkable that the people recognised the medicinal values of this fern, a relict of the once-diverse mangrove swamp forest.

A variety of brooms and mats are common in Ahanve today. They are manufactured from the stems (straw) ofTypha australis and T. domingensis. Stems of these aquatic plants are harvested and dried. For brooms, the strands are bound together at one end and used for sweeping. Straw is skilfully woven to produce mats. Those made from $T$. australis are preferred because the strands are finer, slimmer and are considered to be more beautiful and pleasing to the eye. In addition, $T$. domingensis retains moisture; the mats produced with it are thus less durable. The ethnobotanical uses of aquatic plants enumerated above such as Acrostichum aureum, Typha australis and $T$. domingensis still continue. It is probable that ancient Ahanve people used these plants, i.e. Typha and Acrostichum, for similar purposes in the past as they do today.

\section{Conclusions}

Archaeological and palynological studies carried out in Ahanve, south-western Nigeria, provided insights into the availability and utilisation of aquatic resources during the last 900 years. During the earliest phase of human occupation of Ahanve (9th-17th centuries), the people's diet included freshwater cat-fish (Clariidae) and bivalves (Anodonta sp.); they also engaged in the production of salt. Salt was produced by boiling brine from the Atlantic Ocean in large clay vessels. The archaeological evidence indicated that aquatic resources were supplemented with diverse terrestrial animals (African giant snails, bush meat [baboons?]) and plants (oil palm and kernels [Elaeis guineensis]). In the second occupation phase, aquatic resources such as cat-fish and bivalves declined and subsequently disappeared and salt production was discontinued. In contrast, at the topmost levels (0-20 $\mathrm{cm}$ ) of the sediment core there was an increase in the pollen of herbaceous and weedy plants associated with human habitation and agriculture; this is an indication of a greater reliance on plant as opposed to animal resources. These developments coincided with the trans-Atlantic trade following the arrival of Europeans in Nigeria. During this period, the indigenous method of salt production in Ahanve was discontinued in favour of imported salt. Ethnographic data reveal ethnomedicinal uses of Acrostichum aureum, and the practice of using Typha australis and T. domingensis to produce mats and brooms continues to the 
present day. It is possible that the ancient Ahanve people used these plants for similar ethnobotanical purposes as they do now.

\section{Acknowledgements}

The author is grateful to Chiefs G.J. Toyon, Dosu Toyon and Suru Toyon and the people of Ahanve, particularly Tunde Toyon and Jimoh Toyon, for their assistance and very warm reception during the archaeological excavations. The award of a Doctoral Research Grant to fund the radiocarbon dating by The McArthur Foundation, University of Ibadan, Nigeria, is gratefully acknowledged. Thanks are due also to the two anonymous reviewers.

\section{Bibliography}

Adejuwon, J.O. 1970 'The ecological status of coastal savannas in Nigeria', The Journal of Tropical Geography 30, 1-10.

Alabi, R.A. 1998 An Environmental Archaeological study of the coastal region of southwestern Nigeria, with emphasis on the Badagry area, PhD Thesis, Department of Archaeology and Anthropology, University of Ibadan, Nigeria.

Alabi, R.A. 2002 'Environment and subsistence of the early inhabitants of coastal southwestern Nigeria', African Archaeological Review 19(4), 183-

201. http://dx.doi.org/10.1023/A:1021259003743

Allsworth-Jones, P. and Wesler, K. 1998 'Soil boiling on the Egun Coast: excavation and experiment in Lagos State' in K. Wesler (ed) Historical Archaeology in Nigeria, Trenton, N.J. and Asmara, Eritrea: Africa World Press Inc. 41-73.

Avoseh, T.O. 1938 'A short history of Badagry', Ife-Olu Printing Works.

DeCorse, C.R. 2001 An Archaeology of Elmina: Africans and Europeans on the Gold Coast, 1400-1900, Washington and London: Smithsonian Institution Press.

Erdtman, G. 1966 Pollen Morphology and Plant Taxonomy, New York and London: Hafner Publishing Company.

Faegri, K. and Iversen, J. 1989 Textbook of Pollen Analysis, London: John Wiley and Sons. 
Fishbase Clarias gariepinus (Burchell, 1822) North African

catfish. http://www.fishbase.org/summary/1934 [accessed 05 Aug 2014]

Garlake, P. 1974 'Excavations at Obalara's Land, Ife: an interim report', West African Journal of Archaeology 4, 111-48.

Hossain, H., Jahan, I.A., Nimmi, I., Hossain, M.A. and Kawsar, M.H. 2011 'Anti-inflammatory activity of the ethanolic extract of Acrostichum aureum (Linn.) root', Bangladesh Pharmaceutical Journal 14(2), 107-9.

Khan, S.A., Hossain, M.A., Panthi, S., Asadujjaman, M. and Hossin, A. 2013 'Assessment of antioxidant and analgesic activity of Acrostichum aureum Linn. (family-

Pteridaceae)', Pharmacology Online 1, 166-71.

Morgan, K. 1971 Akinyele's Outline History of Ibadan, Ibadan. The Caxton Press (West Africa) Limited.

Orijemie, E.A. 2013 A Palynological and Archaeological Investigation of the Environment and Human occupation of the Rainforest of South-Western Nigeria during the Late Holocene period, PhD Thesis, Department of Archaeology and Anthropology, University of Ibadan, Nigeria.

Orijemie, E.A. and Sowunmi, M.A. 2014 'Humans and the mangrove in southern Nigeria' in C.J. Stevens, S. Nixon, M.A. Murray and D.Q. Fuller (eds) Archaeology of African Plant Use, Walnut Creek, California: Left Coast Press, Inc. 103-12.

Rivallain, J. 1977 'Le Sel dans les Villages Cotiers et Lagunaries du Bas Dahomey- sa Fabrication, sa Place dans le Circuit du Sel Africain', West African Journal of Archaeology 7 , 143-169

Salard-Cheboldaeff, M. 1980 Palynologie Camerounaise I. Pollens de la mangrove et des fourrés arbustifs côtiers, 105e Congrès nationale des Societes savantes, Caen, Sciences Fasc 1, 233-247.

Salard-Cheboldaeff, M. 1981 Palynologie Camerounaise II. Grains de pollen de la foret litorale de basse altitude, 106e Congrès nationale des Societes savantes, Caen, Sciences Perpignan, Sciences, Fasc.1, 125-136.

Sowunmi, M.A. 1973 'Pollen of Nigerian Plants I. Woody species', Grana 13, 145-86. http://dx.doi.org/10.1080/00173137309429891 
Sowunmi, M.A. 1995 'Pollen of Nigerian Plants II. Woody species', Grana 34, 120-141. http://dx.doi.org/10.1080/00173139509430002

Sowunmi, M.A. 1999 'The significance of the oil palm (Elaeis guineensis Jacq.) in the Late Holocene environments of West and West Central Africa: a further consideration', Vegetation History and Archaeobotany8, 199-

201. http://dx.doi.org/10.1007/BF02342720

Sowunmi, M.A. 2004 'Aspects of Nigerian coastal vegetation in the Holocene: some recent insights' in R.W. Battarbee, F. Gasse, and C.F. Sticklay (eds) Past Climate Variability through Europe and Africa, Dordrecht: Springer. 199-218. http://dx.doi.org/10.1007/978-1-4020$\underline{2121-3 \quad 11}$

Ugwoke, E.V., Umoh, J.U., Okolocha, E.C and Lawal, I. 2013 'Cryptosporidium oocysts in Anodonta sp. (bivalve mollusc) as indicators of pollution of Tiga Lake ecosystem in Kano State, Nigeria', Journal of Parasitology and Vector Biology 5(6), 77-82.

Vitule, J.R.S., Umbria, S.C. and Aranha, J.M.R. 2006 'Introduction of the African catfish Clarias gariepinus(Burchell, 1822) into Southern Brazil', Biological Invasions 8, 67781. http://dx.doi.org/10.1007/s10530-005-2535-8

Walker, I.C. 1975 'The potential use of European clay tobacco pipes in West African archaeological research', West African Journal of Archaeology 5, 165-93.

\section{Personal Communicators}

Chief G.J. Toyon, about 52 years old at 2008; he is the Baale (administrative chief) of Ahanve.

Chief Suru Toyon, at 78 years old was the oldest male in the Ahanve ruling house in 2008.

Tunde Toyon is one of the sons of Chief Suru Toyon. He was about 28 years old in 2008.

Dr Demola Lewis is a lecturer at the Department of Linguistics and African Languages in the University of Ibadan, Nigeria.

Mr Babalola, Babatunde Abidemi is a doctoral student at the University of Rice, USA. 
Mrs Monisola M. Folorunso is a curator in the teaching museum of the Department of Zoology, University of Ibadan, Nigeria. 